\title{
An apocryphal case of craniopagus parasiticus: the legend of Edward Mordake
}

\author{
Anand N. Bosmia • Luke B. Smelser • \\ Christoph J. Griessenauer
}

Received: 17 October 2014 / Accepted: 29 October 2014 / Published online: 7 November 2014

(C) Springer-Verlag Berlin Heidelberg 2014

Conjoined twins fused at the head, or craniopagus twins, occur with an approximate incidence of one in every 2.5 million live births, and such twins represent only 2 to $6 \%$ of conjoined twins [10]. In craniopagus parasiticus, which is also known as épicome [3] or epicomus [8], a parasitic twin head with an undeveloped or underdeveloped body is conjoined to the head of the developed twin [7, 8], as in the case of the "two-headed boy of Bengal" (Fig. 1 and Cover Figure) born in 1783 [3]. The authors briefly discuss the apocryphal tale of an Englishman afflicted with this condition, Edward Mordake (Fig. 2), who has been the subject of various works of art, including Mordake, an opera by the composer Erling Wold [5], and "Chained Together for Life," a song by the singersongwriter Tom Waits, which is featured on his album Alice [6]. Mordake's legend may find a greater audience among fans of the cinematic genre of horror through the fourth season of the American television series American Horror Story, subtitled Freak Show. This season of the series is set in 1952 in Jupiter, FL, and revolves around a troupe of carnival performers with various congenital anomalies [9]. The actor Wes Bentley plays the two-faced character of "Edward Mordrake," whom one of the show's creators, Ryan Murphy, describes as a subject of superstition among carnival performers [9]. Mordake's predicament is detailed in the following passage

A. N. Bosmia $(\bowtie)$

UAB School of Medicine, University of Alabama at Birmingham, 1670 University Boulevard, Birmingham, AL 35233, USA

e-mail: anandb@uab.edu

\section{B. Smelser}

Department of Neurology, University of Alabama at Birmingham, Birmingham, AL, USA

\section{J. Griessenauer}

Department of Neurosurgery, University of Alabama at Birmingham, Birmingham, AL, USA from Anomalies and Curiosities of Medicine by Gould and Pyle, which was first published in 1896 [4]:

"One of the weirdest as well as most melancholy stories of human deformity is that of Edward Mordake, said to have been heir to one of the noblest peerages in England. He never claimed the title, however, and committed suicide in his twenty-third year. He lived in complete seclusion, refusing the visits even of the members of his own family. He was a young man of fine attainments, a profound scholar, and a musician of rare ability. His figure was remarkable for its grace, and his face - that is to say, his natural face - was that of Antinous. But upon the back of his head was another face, that of a beautiful girl, 'lovely as a dream, hideous as a devil.' The female face was a mere mask, 'occupying only a small portion of the posterior part of the skull, yet exhibiting every sign of intelligence, of a malignant sort, however.' It would be seen to smile and sneer while Mordake was weeping. The eyes would follow the movements of the spectator, and the lips would 'gibber without ceasing.' No voice was audible, but Mordake avers that he was kept from his rest at night by the hateful whispers of his 'devil twin,' as he called it, 'which never sleeps, but talks to me forever of such things as they only speak of in hell. No imagination can conceive the dreadful temptations it sets before me. For some unforgiven wickedness of my forefathers I am knit to this fiend - for a fiend it surely is. I beg and beseech you to crush it out of human semblance, even if I die for it.' Such were the words of the hapless Mordake to Manvers and Treadwell, his physicians. In spite of careful watching he managed to procure poison, whereof he died, leaving a letter requesting that the 'demon face' might be destroyed before his burial, 'lest it continues its dreadful whisperings in my grave.' At his own request he was interred in a waste place, without stone or legend to mark his grave."

Gould and Pyle note that Mordake's case was "taken from lay sources" but was "of sufficient notoriety and interest" to be 


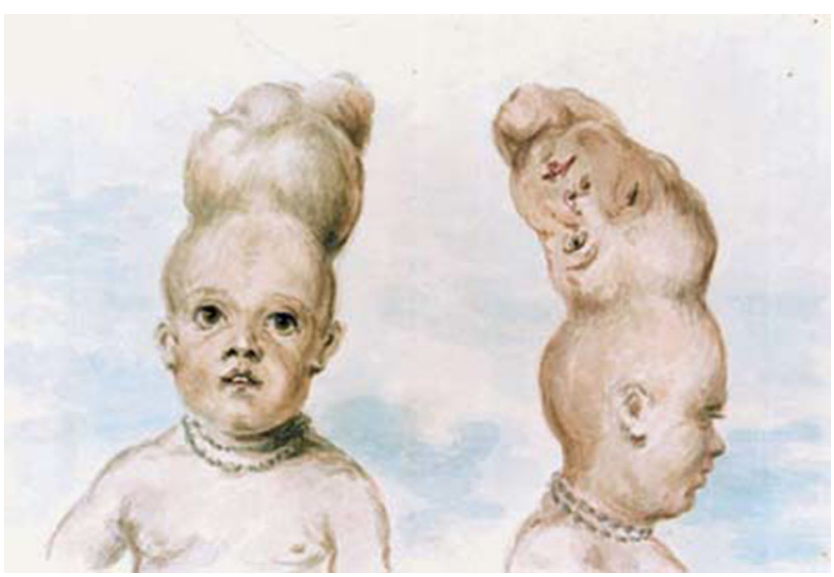

Fig. 1 and Cover Figure Hand-color drawing of the two-headed boy of Bengal by Mr. Dent, salt agent for the Dutch East India Company at Tumloch. Acquired from the article "The Two-Headed Boy of Bengal" by Jan Bondeson, which can be found at http://www.forteantimes.com/ features/articles/148/the_twoheaded_boy_of_bengal.html

included in their book [4]. Its inclusion in Anomalies and Curiosities of Medicine evidently fostered debate as to whether Mordake's case was entirely fictional. In an edition of the Theosophical Review published in 1905, the notion that Gould and Pyle's passage on Mordake is a description of an authentic medical case is met with skepticism [1]. Interestingly, some members of the medical community remained undecided regarding the veracity of Mordake's case decades after the publication of the first edition of Anomalies and Curiosities of Medicine, as evidenced by the following passages:

From an edition of the Journal of the History of Medicine and Allied Sciences published in 1958 [2]: "If this is a genuine case in teratology, there should be authoritative sources for it. The assistance of readers is invited."

From The People's Almanac Presents the Book of Lists, which was published in 1977 [11]: "An heir to a peerage, handsome, gifted as a scholar and musician, Mordake was also gifted with something else which made him very unhappy. On the back of his head he had another face. It was said to be a girl's. Although it couldn't eat or speak, the face's eyes moved; it could also laugh and cry. Edward begged to have his 'devil twin' removed, even if the surgery killed him, but no doctor would attempt it. He committed suicide at the age of 23."

In conclusion, the origins of the story of Edward Mordake are ultimately unknown. Mordake is portrayed in the extant literature as a tortured soul grappling with the sinister persona of his parasitic twin. The authors anticipate that the viewers of American Horror Story: Freak Show will take interest in the

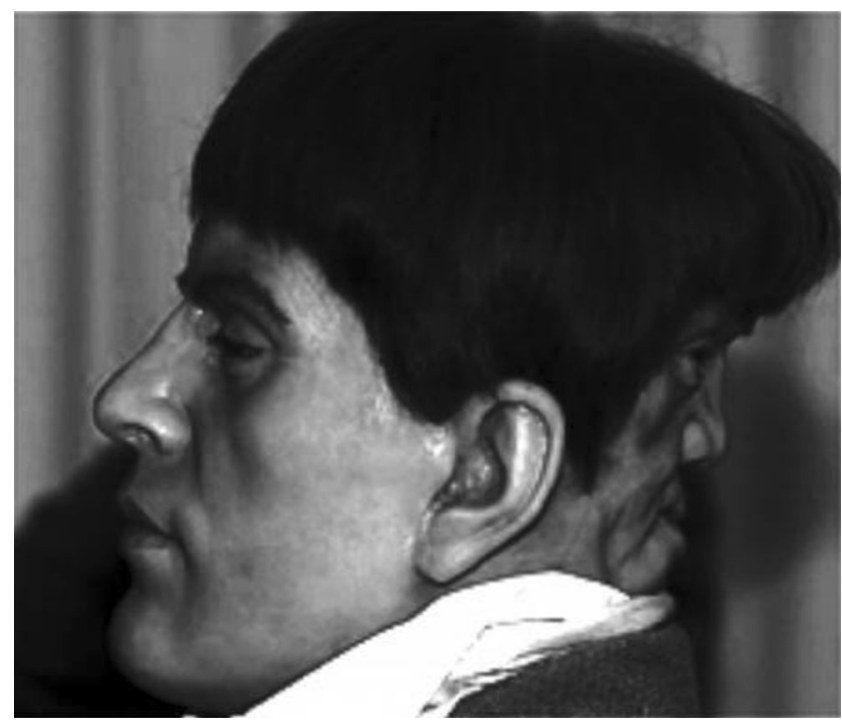

Fig. 2 Wax interpretation of Edward Mordake by an unknown artist. Acquired from the article "Edward Mordake - 'Poor Edward" by J. Tithonus Pednaud, which can be found at http://www.thehumanmarvels. com/from-the-archives-edward-mordake-poor-edward/

legend of Edward Mordake and the medical phenomenon of craniopagus parasiticus.

\section{References}

1. Anon (1905) A very "strange story". Theosophical Rev 37(220):363-364

2. Anon (1958) Notes and events: Edward Mordake. J Hist Med Allied Sci 13(1):99

3. Bondeson J, Allen E (1989) Craniopagus parasiticus. Everard Home's two-headed boy of Bengal and some other cases. Surg Neurol 31(6):426-434

4. Gould GM, Pyle WL (1900) Anomalies and curiosities of medicine. W.B. Saunders, Philadelphia

5. Griffel MR (2013) Operas in English: a dictionary. Scarecrow, Plymouth, Revised edition

6. Hoskyns B (2009) Lowside of the road: a life of Tom Waits. Faber and Faber Ltd, Great Britain

7. Kornienko VN, Pronin IN (2012) Diagnostic neuroradiology. Springer, Berlin

8. Machado LE, Bonilla-Musoles F, Osborne N (2007) Skeletal anomalies. In: Kurjak A, Azumendi G (eds) The fetus in three dimensions: imaging, embryology, and fetoscopy. Informa Healthcare, United Kingdom, pp 341-360

9. Stack T (2014) Ryan Murphy on "AHS: freak show": "this season, once you die, you're dead". Entertainment Weekly. http://insidetv.ew. com/2014/09/15/american-horror-story-freak-show-ryanmurphy/. Accessed 16 Sept 2014

10. Stone JL, Goodrich JT (2006) The craniopagus malformation: classification and implications for surgical separation. Brain 129:1084-1095

11. Wallechinsky D, Wallace I, Wallace A (1977) The people's almanac presents the book of lists. William Morrow and Company, New York 